\title{
THE LAW OF FORCIBLE ENTRY
}

\section{W. F. FOSTER and JOSEPH E. MAGNET*}

The author considers the two contradictory interests which the law on forcible entry must try to harmonize, namely the inviolability of the citizen's dwelling place as against the effective enforcement of the criminal law and civil process. He discusses the common law attitude towards forcible entry in civil and criminal matters and its view of the need for announcement prior to such entry. He also deals with developments in the United States in this area and considers the present state of the law of forcible entry in Canada in the light of the decision of the Supreme Court of Canada in Eccles $v$. Bourque [1975] 2 S.C.R. 739.

\section{INTRODUCTION}

\section{A. Definition of Problem}

"The rule that a man's house is his castle," states Sir Michael Foster, is "perhaps beyond what in the scale of sound reason and good policy it will warrant: but in cases of life we must adhere to rules well known and established."1 Foster's anxiety about the soundness of the "castle" rule is certainly an anxiety of deep concern in both the criminal and civil law today. ${ }^{2}$ It is an anxiety which undoubtedly has its origins in the attempt to reconcile two contradictory interests. As Foster was well aware, the high value which English law places upon the inviolability of a citizen's dwelling infringes of necessity the interest of the commonweal in effective enforcement of the criminal law and civil process. ${ }^{3}$ Expressed in absolute terms the "castle" rule creates a "sanctuary for thieves and murderers."4 Any retreat from what is admittedly an absurd position gives the officers of the King a pass-key to the residences of the nation and a license to use that key in certain vaguely defined situations. 'I'his is a state of affairs with which English law has never been comfortable, ${ }^{5}$ and the confusion of the law on the extent of the license granted is but one of the manifestations of this discomfort. 6

- Mr. Foster is of the Faculty of Law, McGill University; Mr. Magnet is Legal Secretary to Mr. Justice Dickson.

' Foster's Crown Law 319-20 (3rd ed. 1792). Foster goes on to say that the rule should not be extended. (Id. at 319-20.)

2 See Packer, Two Modes of the Criminal Process (1964) 113 U. of Penn. L. Rev. 1; Foote, Tort Remedies for Police Violations of Individual Rights (1955) 39 Minnesota Law Review 493; and Blakely. The Rule of Announcement and Unlawful Entry (1963) 112 U. of Penn. L. Rev. 499. In the United States there has been a furry of legislative activity by the federal and state governments in this area. (For a list of the various state legislation with helpful annotations see Blakely, id. at 561 .

A glance at the Index to Legal Periodicals under search and seizure will demonstrate the depth of academic and judicial concern with the problem-a problem which, according to the commentators, cuts to the heart of constitutional guarantees.

For the Canadian position consult the recent Supreme Court decision of Eccles v. Bourque [1975] 2 S.C.R. 739. This decision has been the subject of a number of comments: see e.g. (1974) 9 U.B.C. L. Rev. 197 and (1975) 7 Ottawa L. Rev.

3 Supra, n. 1 at 320.21 .

I Id.

- Consider Sir William Pitt's remarks in defence of legislation to restrict general warrants of search and seizure: "The poorest man may, in his cottage, bid defiance to all the forces of the Crown. It may be frail; its roof may shake; the wind may blow through it; the storm may enter; but the King of England may not enter, all his forces dare not cross the threshold of the ruined tenement."

As cited in Lasson, The History and Development of the Fourth Amendment to the United States Constitution 49-50 (Ph.D. Thesis, Johns Hopkins University, 1934. in Johns Hopkins University Theses (1937)).

Lasson's work is excellent for a brief account of the early law and we are much indebted to his pioneering study.

- Tension in police-community relations is another. 
Balancing these two interests is a problem as old as law itself. An early legislative solution is present in article 21 of Hammurabi's Code: "If a man makes a breach, into a house, one shall kill him in front of the breach, and bury him in it."6a Deuteronomy 24:11 privileged the house against civil execution. The creditors must "stand abroad, and the man to whom thou dost lend shall bring out the pledge abroad unto thee." A similar principle inheres in the maxim which descends to us from Justinian's Digest, Nemo de domo sua extrahi debet. ${ }^{7}$ In England, forcible entry was criminalized at least as early as the reign of King Edward (940-46). Hamsocne (or hamfare) was "an offence the whole gist of which was solely the forcible entry into a man's dwelling."

\section{B. Constitutional Dimensions}

Article 39 of the Magna Carta created a new orbit for the legislative policies expressed in all early legal systems. That orbit was of constitutional proportions. Article 39 provides: "No free man shall be taken or (and) imprisoned or disseised or outlawed or exiled or in any way destroyed, nor will we go upon him nor send him, except by the lawful judgment of his peers or (and) the law of the land." In the hands of Lord Coke this article became the central focus for protection against arbitrary search and seizure, a problem which in early English law was very serious, and was the subject of immense abuses by the Crown. Reviewing the relevant Star Chamber decrees, one commentator has concluded that there existed virtually "unlimited powers of search and seizure. . . . No limitation seems to have been observed in giving [Star Chamber] messengers powers of search and arrest in ferreting out offenders and evidence." " Into the face of these abuses Lord Coke interjected the last clause of article 39. On the basis of that clause Coke maintained that no forcible entry could be made without a writ, and he severely limited those cases in which a writ could validly be issued. In no case, according to Coke, could a writ be issued on suspicion..$^{10}$

Sir Michael Foster ${ }^{11}$ and Chief Justice Hale disagreed with Coke. Hale, in fact, went beyond Foster in maintaining that "[a] man that arrests upon suspicion of felony, may break open doors, if the party refuses upon demand to open them. . ."12 Blackstone gives limited support to Hale's position but restricts the right of forcible entry on suspicion to those situations where a felony actually had occurred..$^{13}$ Hawkins, on the other hand, is closer to Coke's radical constitutional protection against forced entry on suspicion:

Where one lies under a probable suspicion only, and is not indicted, it seems the better opinion at this day, that no one can justify the breaking open doors in order to apprehend him. ${ }^{14}$

It is this debate which is the origin of the due process clauses in

-. The Code is reproduced in 1 Kocaurek \& Wigmore, Sources of Ancient and Primitive Law 387 (1915).

7 Digest 50.17.103.

- Lasson, supra, n. 5 at 19.

- Id. at 25-6.

104 Coke, Institutes 177.78 (1774). There is a helpful annotation on the entire question in (1961) 76 A.L.R. (2d) 1432 superseding an earlier annotation in (1923) 26 A.L.R. 286.

"Supra, n. 1 at 321. Foster agreed, however, that "bare suspicion" only would not justify forced entry.

121 Hale, Pleas of the Crown 583 (2 vols., 1736).

13 4 Blackstone, Commentaries 292 (4 vols., 1783).

14 3 Hawkins, Pleas of the Crown 184 (7th ed. 1795). This is the position preferred by Nemetz J.A., as he then was, in his dissenting opinion in the British Columbia Court of Appeal in Eccles v. Bourque (1973) 5 W.W.R.
434 (B.C.C.A.). 
both the Fourth Amendment to the United States Constitution and section 1(a) of the Canadian Bill of Rights. Clearly opinion was divided, and the truly difficult point upon which the writers and cases split was, as it still is today, the Crown's ability to break the house on suspicion. In the eighteenth century Pratt C.J. in Huckle v. Money ${ }^{15}$ and Lord Mansfield in Money v. Leach ${ }^{16}$ followed the views of Lord Coke and provided a strong theoretical basis for judicial shrinking of the search power. In the landmark case of Entick v. Carrington, Pratt (then Lord Camden L.C.J.) framed the question in this way:

By the laws of England every invasion of private property, be it ever so minute, is a trespass . . . According to this reasoning, it is now incumbent upon the defendants to show the law, by which this seizure is warranted. If that cannot be done, it is a trespass. ${ }^{17}$

Lord Camden went on to find the origin of general search warrants in illegal practices of Star Chamber and thus entirely without foundation in law. Encouraged, as this holding was, by the seventeenth century writers, and particularly by Coke, this classic decision, as Mr. Justice Bradley has noted, ${ }^{18}$ ties constitutional chains around arbitrary power of entry and search. As such, there is every reason to believe that limitation on the search power is an inherited principle of Canadian law not only through the lineage of common law, but originally by constitutional law as well.

The extent of this constitutional limitation, if so it be, presents an intriguing challenge to Canadian law. For it is certainly clear that judicial review of legislative powers virtually expired in England in the early seventeenth century. Any remaining embers were extinguished by the growth in the doctrine of Parliamentary sovereignty. If article 39 of Magna Carta and the constitutional jurisprudence based on it ceased to serve as constitutional borders beyond which it was impermissible to exercise entry and search powers in British law, the Canadian Bill of Rights raises important issues touching the question of whether or not constitutional protection against entry powers can be afforded by means of judicial review of legislative powers. The Bill of Rights is a direction by Parliament to the judges to monitor the acts of Parliament insofar as such acts conflict with the values protected by the Bill of Rights. The judges, of course, at Parliament's direction, will act in obedience to Parliament. But the question arises, from where can the judges derive guidance in interpreting the broad general language of the Bill of Rights? Section 1(a) of the Bill of Rights echoes the language and precisely the concept which had been responsible for the rapid development in constitutional protection against arbitrary powers of forcible entry. The terms of this protection was the concept of "due process of law" applied by Lord Coke. It is suggested that since section 1(a) of the Bill of Rights is cast in the mold of ancient constitutional protections, the best guidance for judicial interpretation of the phrase, in the context of forcible entry, would be the seventeenth century cases and doctrine. In that vein there is every reason to believe that the radical protection which Lord Coke afforded against abuse of forcible entry

\footnotetext{
is (1763) 95 E.R. 768.

16 (1765) 97 E.R. 1050 at 1075.

17 (1765) 19 St. Tr. 1030.

10 Mr. Justice Bradley in Boyd v. United States (1868) 166 U.S. 616 at 626 called the Entick decision "one of the permanent monuments of the British Constitution."
} 
powers is an arguable constitutional principle in current Canadian law. The extent to which these constitutional protections bind the search power must now command our attention.

\section{COMMON LAW DEVELOPMENTS}

\section{A. Common Law Rules Pertinent to Forcible Entry in Civil Process}

Much of the confusion in the common law power of entry is the result of a failure to distinguish between the differing situations which obtain in the civil and criminal processes. ${ }^{19}$ The Year Books, which unfortunately seem not to have been followed consistently in subsequent jurisprudence, set out the distinction with crystal clarity:

For a felony, or suspicion of a felony, one may break into the dwelling house to take the felon, for it is for the common weal and to the interest of the King to take him; but it is otherwise as to debt or trespass; the sheriff or any other may not break into his dwelling to take him, for it is only the private interest of the party. ${ }^{20}$

Semayne's Case, ${ }^{21}$ the leading case on forcible entry, was in fact a civil case. It laid down six general principles which have been widely followed:

1. The house of every one is his castle. ... and the owner ... [may] kill in defence of himself and his house, [and] it is no felony and he shall lose nothing.

2. Where any house is recovered by any real action, ... the sheriff may break the house and deliver the seisin or possession.

3. In all cases where the King is party, the sheriff may break the house, either to arrest or do other execution of the King's process, if he cannot otherwise enter. But he ought first to signify the cause of his coming, and make request to open the doors.

4. Where the door is open the sheriff may enter, and do execution at the suit of a subject, and so also in such case may the lord, and distain for his rent or service. It is not lawful for the sheriff, on request made and denial, at the suit of a common person, to break the defendants' house, scil. to execute any process at the suit of a subject.

5. The house of any one is only a privilege for himself, and does not extend to protect any person who flies to his house, or the goods of any other which are brought there, to prevent a lawful execution and to escape the process of the law: in such cases after request and denial, the sheriff may break the house.

6. If the sheriff might break open the door to execute civil process, yet it must be after request made. ${ }^{22}$

Excepting seizure of land, then, the rule that one cannot enter forcibly for the execution of a civil process, including civil arrest, appears to be well established in the subsequent cases. ${ }^{23}$ Entry through an open door, the situation contemplated by the fourth rule in Semayne's Case, has been held not to be a forcible entry. ${ }^{24}$ Very early the privilege was limited to a dwelling house ${ }^{25}$ and later cases have upheld this..6 The

19 As Blakely, supra, n. 2 at 501, has noticed: "The extent to which privileges of the house extended to criminal rather than civil arrests seems never to have been considered squarely."

20 (1455) Y.B. 13 Edw. IV 9a, cited in Wilgus, Arrest Without a Warrant (1924) 22 Mich. L. Rev. 541800

21 (1604) 5 Co. Rep. 91 a; 77 E.R. 194.

22 Id.

2.] E.g., in Burdett v. Abbott (1811) 14 East 1, 104 E.R. 501 at 506 the court stated that "the law values the private repose and security of every man in his own house, which it considers as his castle, beyond the civil satisfaction of a creditor"; in Seyman v. Gresham (1688) Cro. Eliz. 908, 78 E.R. 1131 the court held that a house was privileged against execution but (at 1131) noted that on a Capius ultagatum the sheriff "may well enter any man's house to apprehend him: for no place ought to protect him against the Queen; and he being out of the law, shall not have the protection of the law." See also Cook's Case (1640) Cro. Car. 537, 79 E.R 1063; Foster v. Hill (1688) 1 Bulstrode 146, 80 E.R. 839, Whalley v. Williamson (1836) 7 Car. \& P. 294,173 E.R. 130; and Kereby v. Denky (1836) 1 M. \& W. 336, 150 E.R. 463.

24 Lloyd v. Sandilands (1818) 8 Taunt 250, 129 E.R. 379.

${ }^{25}$ Penton v. Brown (1864), 83 E.R. 1193. See also Blakely, supra, n. 2 at 501. 
privilege extends only to an outer door. ${ }^{27}$ Lord Mansfield, in holding that an inner door could be forced, was contemplating the situation of a rooming house in which the initial entry through the outer door was peaceful. ${ }^{28}$ Entry by subterfuge or trick in civil process is justifiable. ${ }^{29}$ As the fifth rule in Semayne's Case indicates, the privilege only extends to the householder in his own home; it is justifiable to enter the house of a third party to execute civil process against the one sought or his goods but if the party sought should not be on the premises, the justification does not hold and the officer is guilty of trespass. ${ }^{30}$ In Eccles v. Bourque the Supreme Court of Canada has reaffirmed this rule. ${ }^{31}$ It would appear that there is no case on the books where the requirement of announcement hefore entry in civil process can be justifiably abrogated. Although the point is disputed, the better opinion seems to be that announcement is a prerequisite before forcible entry of a non-dwelling or before breaking inner doors. ${ }^{32}$ Even where announcement has been made, the courts have recognized the desirability of restraint before breaking inner

26 See e.g., R. v. Curtis (1756) Foster 135, 168 E.R. 67 at 68, where it was held for the civil process of arrest "peace officers . . . may break open doors [of a workshop] after having demanded admittance and given due notice of their warrant"; and Hodder v. Williams [1895] 2 Q.B. 663 at 666, where Lord Esher held that the only distinction is between a dwelling house and a building which is not a dwelling house.

27 Lee v. Gansell (1774) 1 Cowp. 1, 98 E.R. 935. In Lloyd v. Sandilands (1818) 8 Taunt. 250, 129 E.R. 379 at 380. Borrough J. held that "when the outer door is open the bailiff may enter forcibly, either through an inner door or a window." Dallas J. explained this by pointing out that "if the outer door be broken, it lays the house open to invasion of all sorts of persons but where the inner door is broken, that is not the case" (id.). The 17th century reasoning that a man's house is not only a castle, but a fortress, persists in the later cases although high volume high rise residences do seem to make such reasoning obsolete. (Ratcliffe v. Burton (1802) 3 Bos. \& Pul. 223, 127 E.R. 123.) There is also good American authority on this point (e.g.People v. Hubbard (1840) 24 Wend. 386 (N.Y.).

2* Lee v. Gansell (1774) I Cowp. 1, 98 E.R. 935. And see Blakely, supra, n. 20 at 501, footnote 17.

2v Waterhouse v. Saltmarsh (1724) 80 E.R. 409; R. v. Backhouse (1772) 98 E.R. 533. Blakely, supra, n. 2 at 501, thinks this point is not clear but Wilgus, supra, $\mathrm{n} .20$ at 806, and Perkins, The Law of Arrest (1940) 25 Iowa L. Rev. 201 at 207, agree that entry by subterfuge or trick is justifiable on the strength of the authorities.

3o Parke v. Evans (1615) 80 E.R. 211; Johnson v. Leigh (1815) 6 Taunt. 246, 128 E.R. 1029; Morrish v. Murray (1844) 13 M. \& W. 52, 153 E.R. 22; Ratcliffe v. Burton (1802) 3 Bos. \& Pul. 223, 127 E.R. 123; and Southam v. Smart [1964] 1 Q.B. 308. Mr. Justice Robertson of the British Columbia Court of Appeal examined these cases in Eccles v. Bourque [1973] 5 W.W.R. 434 and concluded that the inclination of the courts seems "to be designed to protect householders from interference with their liberty in their own house and to be less solicitous of interference with the liberty of persons who are in other people's houses" at 440. Although this correctly expresses the position in law, no sound reason for the distinction has been advanced in the cases. If it be desired to abrogate sanctuary, it would seem logical to extend the rule to the suspect's house. If the violence of forcible entry is abhorred by the law, protection certainly ought to extend to the premises of an innocent and perhaps unsuspecting third party. Mr. Justice Robertson's approsch has been criticized in a comment in (1974) 9 U.B.C.L. Rev. 197 at 202.

Mr. Justice Dickson in the Supreme Court of Canada's decision in Eccles v. Bourque (1975) 2 S.C.R. 739 considered the distinction in relation to a criminal fugitive and concluded: "I am unable to find any AngloCanadian authority supporting a distinction of this nature and in principle it seems to' me to be wrong" at 744. With admirable logic and clarity Mr. Justice Dickson went on to say that: "The fact that the premises to be entered are those of a third party may have a bearing in the determination of reasonable and probable cause" (id.). This would appear to constrict the entry power respecting third party premises. At least more care would appear to be necessary in determining whether the furgitive is on the premises. In the author's view, Diclson J.'s holding on this matter is the first sensible approach to the distinction in the reported cases.

it "In the case of civil process the rule is that if a sheriff s officer enters the house of $A$ to execute process against the goods of B or to arrest B he enters at his peril and if the goods or B, as the case may be, are not present, he is guilty of trespass" per Dickson J. (id. at 744.)

:2 Ryan v. Shilcock (1851) 7 Ex. 70, 155 E.R. 861, states the contrary position. Relying on Hutchison v. Birch (1812) 4 Taunt. 1019, 128 E.R. 473, and Lloyd v. Sandilands (1818) 8 Taunt. 250, 129 E.R. 379, Blakely, supra, n. 2 at 501 , remarks that "[a]nnouncement was required neither before inner doors not prior to entry into a non-dwelling." Certainly the third rule in Semayne's Case (1604) 5 Co. Rep. 91a. 77 E.R. 194, provides for the contrary principle as do Waterhouse v. Saltmarsh (1724) 80 E.R. 409, and Ratcliffe v. Burton (1802) 3 Bos. \& Pul. 223, 127 E.R. 123. In the Waterhouse case the Star Chamber reprimanded and fined the Sheriff for "the unnecessary terror and outrage of this arrest, and for not signifying that he was the sheriff, that the door might have been opened without violence." (Id. at 409.) Ratcliffe v. Burton touches a similar kind of reason, and develops the thinking of the law in a cohesive and persuasive way that the later cases seem not to have appreciated. "Such conduct must tend to create fear and dismay, and breaches of the peace provoking resistance," wrote Mr. Justice Heath. Id. at 126. He pointed out that failure to meet the requirement of announcement "would not only be attended with great mischief to the persons against whom process is issued, but to other persons also, since it must equally hold good in cases of process upon escape where the party has taken refuge in the house of a stranger." Id. at 126-27. The point, emphasized by Mr. Justice Rook, is that the chances of violence will be substantially reduced by giving notice. Id. at 127. Lord Alvanley C.J. pointed out that "[i]t has never been said however, that the officer may justify breaking the inner doors without averring a previous demand of peaceable admittance, or showing why such violence was necessary." (Id. at 126.) 
doors. $^{33}$ Lord Mansfield, always energetic to pursue debtors, made the point this way:

It is much better therefore, says the law, that you should wait for another opportunity, than to so an act of violence, which may probably be attended with such dangerous consequences. 34

Processes flowing from contempt of court or of the legislature are treated under the rules pertaining to criminal process..$^{35}$ It should be noted that authority is divided on whether or not forcible entry is justifiable in a civil process at the suit of the Crown. English dictum privileges the dwelling against the King ${ }^{36}$ while Canadian authority, in all situations in which the Crown is a party, would authorize forcible entry ${ }^{37}$ Finally, the cases are clear that rearrest on a civil warrant will justify forcible entry. ${ }^{38}$ Although the theory of the cases is based upon an escape having occurred, fresh pursuit does not appear to be a requirement. Thus, one can return with help and break open doors. ${ }^{39}$ The necessity of announcement is maintained in this situation..$^{40}$

\section{B. Common Law Rules Pertinent to Forcible Entry in Criminal Process}

In general, after due demand and refusal, a peace officer may make a forcible entry to arrest a felon on a criminal process. ${ }^{41}$ Such entry may be made either with or without a warrant. ${ }^{42}$ The entry may be made in the night as well as in the day..$^{43}$

There has been considerable controversy among the authorities about the right forcibly to enter on suspicion of a felony. Hawkins and Foster were clear that without a warrant an officer could not break doors on

33 See Blakely, supra, n. 2 at 501.

34 Lee v. Gansell (1774) I Cowp. 1, 98 E.R. 935 at 938.

3s Burdett v. Coleman (1811) 14 East 163, 104 E.R. 563; Howard v. Gassett (1842) Car. \& M. 380, 174 E.R. 553; Harvey v. Harvey (1884) L.R. 26 Ch. D. 644. And see infra at n. 61.

36 See e.g. Seymane's Case (1604) 5 Co. Rep. 91a, 77 E.R. 194 and Burdett v. Abbott, (1811) 4 East. 1, 104 E.R. 501 at $560-61$.

37 "The right to break open the outer door to arrest plaintiff is not confined to cases of felony but extends to misdemeanours, breaches of the peace, and other matters of general concern in which the public at large have an interest, and to which the Queen is a party": Van Tassel v. Trask (1894) 27 N.S. R.329. The Court in the Van Tassel case hold that a valid warrant and notice were prerequisite to a justified forced entry. See also Seymane's Case (1604) 5 Co. Rep. 91a, 77 E.R. 194; and Seyman v. Gresham (1688) Cro. Eliz. 908, 78 E.R. 1131 .

38 Aga Kurboolie Mahomed v. The Queen (1843) 4 Moore 239, 13 E.R. 293. In this case the peace officers were forcibly expelled from the premises and had the outer door locked on them after they had peaceably gained entry. The officers then forcibly re-entered the premises. In upholding the conduct of the officers Lord Campbell stated that since Mahomed had "unlawfully caused them to be expelled ... he cannot be permitted to take advantage of his own wrong" and that the officers "had a right to place themselves in the position which they occupied when his unlawful act began." (Id. at 296.) And see Anonymous (1774) Lofft. 390, 98 E.R. 709; Anonymous (1702) 7 Mod. 8, 87 E.R. 1060; and Sandon v. Jervis (1858) 120 E.R. 758. The latter case is of interest on the facts. The officer reached in through a window touching the one for whom he had a warrant. the court held that at that point the fugitive was a prisoner and the officer was justified in making forcible entry to take his prisoner away. This point had been made earlier in Lloyd v. Sandilands (1818) 8 Taunt. 250, 129 E.R. 379.

39 Aga Kurboolie Mahomed v. The Queen (1843) 4 Moore 239, 13 E.R. 293.

10 The point is clear in the American cases: See e.g., Com v. McGahey (1858) 11 Gray 194 (Mass.); Allen v. Martin (1833) 10 Wend: 300, 25 Am. Dec. 564 (N.Y.). But see also Aga Kurboolie Mahomed v. The Queen (1843) 4 Moore 239, 13 E.R. 293

1 The common law rules of forcible entry in criminal process developed within the common law distinction between misdemenour and felony. For present purposes it seems entirely feasible to treat the Canadian distinction between indictable and summary offences as roughly congruent to the common law distinction. This certainly would be the most lorical interpretation of 8.450 of the Canadian Criminal Code which is effectually a codification of the common law. The rules which 8.450 state in terms of the indictable-summary offence distinction were originally formulated in common law categories. In stating the position at Canadian law we have maintained a congruence of the common law and Criminal Code distinctions.

${ }^{2}$ (1455) Y.B. 13 Edw. IV 9a, supra, n. 20; Semaynes Case (1604) 5 Co. Rep. 91a, 77 E.R. 194; Seyman v. Gresham (1688) Cro. Eliz. 908, 78 E.R. 1131; Burdett v. Abbott (1811) 14 East 1, 104 E.R. 501; Davis v. Russell (1820) 5 Bing. 354, 130 E.R. 1098. In Hancock v. Baker (1800) 2 Bos. \& Pul. 260, 126 E.R. 1270, where a private person entered to prevent a murder, Chambre J. stated at 1273 that "[i]t is lawful for a private person to do anything to prevent the perpetration of a felony." The other judges were more cautious in their language.

43 Davis v. Russell (1820) 5 Bing. 354, 130 E.R. 1098: "Severity is not necessary . . . but it is necessary that the constables should have their persons secure": per Best J., at 1102. 
suspicion. ${ }^{44}$ Both thought breaking doors an extreme and dangerous situation. Foster put the point in this way:

[B]are suspicion touching the guilt of the party will not warrant a proceeding to this extremity, though a felony hath been actually committed; unless the officer cometh armed with a warrant from a magistrate grounded upon such suspicion. ${ }^{45}$

This view in general has prevailed in the United States where searches without a warrant are held by the United States Supreme Court, subject to certain exceptions, to be per se unreasonable. ${ }^{46}$ The American thinking here is influenced by the desirability of placing a "neutral and detached magistrate" between the conflicting interests of private security from interference and zealous prosecution of criminals for enforcement of the law. ${ }^{47}$ Lord Coke maintained that entry on suspicion of a felony was contrary to Magna Carta. ${ }^{48} \mathrm{He}$ prohibited not only entry without a warrant in such a situation, but the issuance of a warrant as well.49

Contrary authority appears in the early dicta of the Year Books. ${ }^{50}$ This is supported by Blackstone who limits justified entry to situations in which a felony has actually occurred; that event only authorizes the entry. ${ }^{51}$ The strongest support for the right of the peace officer forcibly to break doors on suspicion of felony comes from Chief Justice Hale. According to Hale, the authority extends to a private citizen "if he sees danger of murder by a dangerous wound given .... in both these cases he may break open doors, if he be denied entrance,.... for the law makes him an officer in this case as well as if he were a constable."52 Blackstone disagreed that a private citizen could forcibly enter on reasonable suspicion of a felony ${ }^{53}$ and the cases in the main have supported his view. ${ }^{54}$ Since the cases are clear that a private citizen can forcibly enter to arrest one either about to commit or in the process of committing a felony, ${ }^{55}$ the present position in law would seem to be that only the event of the intercepted or completed felony can justify the forcible entry of a private citizen, unless he is a member of an arresting party.56 Reviewing only the textual authorities, not the jurisprudence, an American commentator has suggested that "the rule appears to be that an officer can break doors under the common law when he is authorized to arrest."57 From what can be gleaned from the cases, this is almost certainly wrong and, on principle, undesirable. ${ }^{58}$ Equally, the rule,

14 3 Hawkins, supra, n. 14 at 184; and Foster, supra, n. 1 at 321.

is Foster, supra, n. 1 at 321.

46 "Searches conducted outgide the judicial process, without prior approval by judge or magistrate, are per se unreasonable under the Fourth Amendment-subject only to a few specifically established and well-delineated exceptions." (Katz v. United States (1967) 389 U.S. 347 at 357. ) It has been maintained, however, that searches incident to arrest fall within the exceptions. See generally Comment (1970) 80 Yale L.J. 139 at 169 footnote 126.

4: Johnson v. United States (1948) 333 U.S. 10 at 14.

4s See supra, nn. 43 and 44.

404 Coke, supra, n. 10 at 177.78 .

so See supra, n. 20.

si 4 Blackstone, supra, n. 13 at 292.

s2 2 Hale, supra, n. 12 at 77 , citing the Y.B. 7 Edw. III 16 \& 16 b.

s. 4 Blackstone, supra, n. 13 at $289 \& 293$.

s4 Smith v. Shirley (1846) 136 E.R. 58; Rockwell v. Murray (1850) 6 U.C.Q.B. 412. But see also Handcock v. Baker (1800) 126 E.R. 1270.

ss Handcock v. Baker (1800) 126 E.R. 1270.

so See Wilgus, supra, n. 20 at $798-99$ and footnotes $602-13$.

s7 Blakely, supra, n. 2 at 502 footnote 23.

so Certainly this is wrong in respect of a private person (see supra, $n$. 54) and the wide powers of arrest at common law undercut totally the protections of the home on which all authorities agree. The reasoning of 
synthesized from American cases, that a forcible entry without warrant can be made on suspicion of felony, ${ }^{59}$ is of marginal assistance in determining the position at common law.

The solution to the problem of whether or not at common law a peace officer may forcibly enter a dwelling house without a warrant on the suspicion that the fugitive is on the premises might be found in the cases dealing with contempt. As Lord Ellenborough C.J. pointed out, a contempt proceeding is assimilated to the criminal process. ${ }^{60}$ That the same rules of entry apply in contempt as in criminal process has been noticed in subsequent cases. ${ }^{61}$ Burdett v. Colman, ${ }^{62}$ the first case, held that officers of the House of Commons were justified in breaking doors to search for the plaintiff sought on a House warrant. A similar right to search was maintained in two subsequent cases. ${ }^{63}$ Since at common law the right to search does not follow the right to arrest, ${ }^{64}$ the three cases may serve as authority for the narrower proposition that a peace officer reasonably suspecting the fugitive is on the premises, in criminal process may forcibly enter to search. Although the American position draws a distinction between the fugitive's home and third party premises-forcible entry on third party premises is prohibited unless the officer has a warrant and enters on resonable and probable grounds, or the fugitive is actually found on the premises ${ }^{65}$-the Supreme Court of Canada has declined to follow this distinction. ${ }^{66}$ Finally, in addition to the proposition that forcible entry may be made by a constable suspecting the felon is on the premises, authority exists to support the right of forcible entry on suspicion that a felony has been committed.67 The suspicion, however, must be reasonable, thus assuring judicial guidance in maintaining standards of protection from unreasonable interference. ${ }^{68}$ In consideration of these two rules, the only consistent

Johnson v. United States (1948) 333 U.S. 101 would be the better opinion. It seems ill-considered to treat forcible entry without a warrant as anything but an extraordinary procedure, one that requires strict procedural controls. (N.B. We are confirmed in our opinion that this rule is wrong by the opinion which has just been delivered by the U.S. Supreme Court in U.S. v. Watson, No. 74-538, Jan. 26, 1976 in which Mr. Justice Stewart noted: "The Court does not decide, nor could it decide in this case, whether or under what circumstances an officer must obtain a warrant to effect an arrest".)

39 "In case a felony has been committed the right to break doors to arrest, follows the right to make the arrest, under rules 3 and 4; the officer, if necessary, may break doors in arresting one who has committed a felony, or one who he has reasonable grounds to believe has committed a felony, whether a felony has or has not been committed. . . ." (Wilgus, supra, n. 20 at 803.' The same author goes on to note that a private person cannot forcibly enter for felony unless it was actually committed. (Id.) U.S. v. Watson, No. 74-358, Jan. 26, 1976, now reveals that this proposition does not hold in the United States either.

60 After pointing out that the liberty of the house holds at the suit of the King for debt or trespass, Lord Ellenborough said: "the interest of the King in the execution of process seems only to be put in contradistinction to the interest of an individual in process sued out for his own particular benefit; inasmuch as the process of the Crown respects the public justice and public interest of the realm: but is is not put in contra. distinction to process for contempt, in which the public at large have as much interest as in other criminal process": Burdett v. Abbott (1811) 14 East 1, 104 E.R. 501 at 560 . Mr. Justice Robertson called attention to the assimilation of contempt to the criminal process in Eccles v. Bourque [1973] 5 W.W.R. 434 (B.C.C.A.).

6 In Harvey v. Harvey (1884) L.R. 26 Ch. D. 644, Mr. Justice Chitty considered the distinction between an order for committal and an attachment for contempt and, following Jessel M.R. in Sprunt v. Pugh (1877-78) 7 Ch. D. 567, noted that it was practically abolished (at 655). This ought to govern the Canadian distinction between civil and criminal contempt, unless an artificial ground be sought for narrowing the privilege to break doors. In Anonymous (1744) Willes Rep. 459, 125 E.R. 1267, at 1267, the reason for the assimilation of contempt to the criminal process was noted as being that contempt "was a breach of the peace."

62 (1811) 14 East 163, 104 E.R. 563.

63 Howard v. Gossett (1842) Car. \& M. 380, 174 E.R. 553 (House of Commons warrant for arrest for contempt); Harvey v. Harvey (1884) L.R. 26 Ch. D. 664 (warrant of arrest for contempt of court).

64 See supra, nn. 57.59.

6s See e.g., State v. Brown (1854) 5 Del. 505; Com. v. Reynolds (1876) 120 Mass. 190. Hale held the contrary view (supra, n. 12 at 117). McCastin v. McCord (1906) 116 Tenn. 693, should also be consulted.

66 Eccles v. Bourque [1975] 2 S.C.R. 739 at 744- 46.

67 Davis v. Russell (1820) 5 Bing. 354, 130 E.R. 1098.

6. "The question of probable cause is, no doubt, a question for the Judge; but the jury must first find the facts which are supposed to constitute the probable cause; and it is sometimes difficult to draw the line between law and fact" per Best C.J. (Id. at 1101.) 
ground for rationalizing the textual authorities is to treat such an entry as a highly extraordinary act. As such, it would require a highly extraordinary set of circumstances to justify the entry. ${ }^{69}$ From the interests involved, an even more stringent test would have to be met to authorize such entry on third party premises. ${ }^{70}$ It should be noted, however, that Davis v. Russell $7^{0 a}$ is the only authority found for the proposition that forcible entry without warrant may be made on suspicion of felony, as opposed to suspicion that the felon is on the premises.

A peace officer may make a forcible entry without a warrant for a misdemeanour committed in his presence. ${ }^{71}$ An entry for misdemeanour not committed in his presence is not justified.72 American cases are helpful in delimiting the meaning of "in the officer's presence." The point is made that a misdemeanour is deemed committed in the officer's presence "when he can see from the outside that a crime is being committed inside ... a crime is considered as being committed in the presence of view of an officer when any of his senses affords him knowledge that it is being committed."73 The use of the word "senses" seems to be the key and suggests that a wide authority is not contemplated. Thus the American cases suggest that a mere belief that a misdemeanour is being committed will not suffice to justify forcible entry; ${ }^{74}$ nor will a verbal complaint ${ }^{75}$ or a radio call. The paradigm situation appears to be that in which "one assaults another in the presence of the officer (a misdemeanour), and then takes refuge in his home."76 This may be opposed to peeking through a knothole or trespassing "with the object of discovering a misdemeanour,"77 which will not suffice to attract justification for forced entry without a warrant.

It follows from the requirement that the misdemeanour be committed in the officer's presence that no forcible entry without warrant may be

69 Mr. Justice Nemetz (dissenting) in Eccles v. Bourque (1973) 5 W.W.R. 434 at 450, demonstrated a sound and Bensible appreciation of the point, and his criteria for withholding justification for the forced entry deserve consideration: "(1) the police officers were not in hot pursuit; (2) they appeared at the door in plain clothes; (3) the door they approached was that of a stranger to the proceedings between the Crown and the fugitive; (4) they were visibly armed; (5) they pushed the respondent aside and entered without first asking his permission; (6) they gave no explanation for desiring entry until after searching the suite; and (7) in fact the fugitive was not in the suite." in the U.S. there is also a lively debate on the extent of authority for forcible entry without warrant. As noted above, Katz v. United States (1967) 389 U.S. 347, held searches without warrant per se unreasonable. This is subject to the exception of "exigent circumstances" in which obtaining a search warrant may be impractical, although probable cause to search (Fourth Amendment) is still a necessary ingredient of the authority. "In enforcing the Fourth Amendment's prohibition against unreasonable searches or seizures the Court has insisted upon probable cause as a minimum requirement for a reasonable search permitted by the Constitution . . . Only in exigent circumstances will the judgment of the police as to probable cause serve as a sufficient authorization for a search." (Chambers v. Maroney (1969) 399 U.S. 42 at 51.) Since destruction of evidence has been held to be an exigent circumstance in the U.S. zealous prosecution of narcotics offences presents a nice problem in confining the power. A heipful approach is Vale v. Louisiana (1969) 399 U.S. 30. But see also Schmerber v. California (1965) 384 U.S. 757.

70 There is judicial authority, although slight, for the proposition. "The fact that the premises to be entered are those of a third person may have a bearing in the determination of reasonable and probable cause. There may be less likelihood of a fugitive being in the home of another than in his own home": per Dickson J. (Eccles v. Bourque [1975] 2 S.C.R. 739 at 744). It would be desirable to extend this finding to the very justification itself. There should be less room for justification in entering third party premises in this extraordinary way.

20. (1820) 5 Bing. 354, 130 E.R. 1098.

il $R$. v. Smith (1833) 6 C. \& P. 136, 172 E.R. 1178. The authority is weak. It was a public house and the door was ajar. Wilgus, supra, n. 20 at 803 footnote 638, cites an array of American authorities.

i2 $R$. v. Preble (1858) I F. \& F. 325, 175 E.R. 748. This was a barn attached to a public house. Bramwell B. at 748 , noted that "[i]t would have been otherwise had there been a nuisance or disturbance of the public peace, or any danger of a breach of the peace."

is Griffin v. State (1952) $92 A$ (2d) 743, 345 U.S. 907.

is Adair v. Williams (1922) 24 Ariz. 422, 210 p. 853.

$7 s$ Jamison v. Gaernett (1874) $73 \mathrm{Ky}$. (10 Bush) 221.

76 St. Paul v. Webb (1959) 256 Minn. 210, 97 N.W. (2d) 638.

is Smith v. State (1926) 244 P. 52. Consult (1962) 76 A.L.R. (2d) 1432, for general annotation on forcible entry for misdemeanour. 
made on suspicion of misdemeanour. In no case may a forcible entry be made without a warrant to arrest for a misdemeanour which is not in the order of a breach of the peace, ${ }^{78}$ as, for example, talking loudly in the presence of an officer, ${ }^{79}$ or urinating in the street. ${ }^{80}$ Since an arrest without a warrant may not be made for a past misdemeanour, ${ }^{81}$ a similar prohibition attaches to forcible entry without warrant for a past misdemeanour, even if the misdemeanour has been committed in the officer's presence. ${ }^{82}$ Private citizens may not make a forcible entry to arrest for a misdemeanour. ${ }^{83}$

\section{THE REQUIREMENT OF ANNOUNCEMENT}

An American commentator has convincingly summed up the present state of American law on the requirement of announcement before forcible entry as follows: "Most states have no clearly articulated body of precedent in the area of announcement and entry. Almost every arrest situation has become, therefore, a case of first impression." 84 It is far from a happy situation, and the recent flood of American legislation has only further obfuscated an already murky picture. ${ }^{85}$ The same writer suggests that the rules at common law were by no means more rational ${ }^{86}$ and the best solution would be abolition of the announcement requirement in favor of narrowing and clarifying the right of forcible entry. ${ }^{87}$

In respect of common law, the attack would appear to be overstated. High Canadian authority, at any rate, gives a clear uncontradicted statement of the law. ${ }^{88}$ Recently, however, the Supreme Court of Canada adopted precisely the language and categories of the American cases. ${ }^{89}$ It may be that in the absence of a legislative morass the Court can refine the announcement rule. If this approach is preferred to abolition, the common law deserves closer attention than it has received. There is every reason to believe, as will appear from what follows, that the old common law judges had a sounder grasp of the rationale for the announcement rule than does recent American authority.

The correct view of the position at common law would appear to be stated in a recent article: "By 1791 the need for notice before officials could forcibly enter was firmly established in England."90 Certainly the eighteenth century text writers were of one mind that announcement

7s Wilgus, supra, n. 20 at 703. And see Levy v. Edwards (1823) 1 C. \& P. 40, 171 E.R. 1094; Booth v. Hanley (1826) 2 C. \& P. 288, 172 E.R. 129; R. v. Bright (1830) 4 C. \& P. 387, 172 E.R. 752;. Fox v. Gaunt (1832) 3 B. \& Ad. 798, 110 E.R. 293.

79 Hardy v. Murphy (1795) 1 Esp. 294, 170 E.R. 362.

so Booth v. Hanley (1826) 2 C. \& P. 288, 172 E.R. 129.

st Wilgus, supra, n. 20 at 701-703.

*2 R. v. Marsden (1868) L.R. 1 C.C.R. 131.

*s Rockwell v. Murray (1850) 6 U.C.Q.B. 412.

Bt Blakely, supra, n. 2 at 553.

ns While search warrants are governed by federal statute 18 U.S.C. No. 3109 (1958) arrests fall under state laws: Miller v. United States (1958) 357 U.S. 301 . There is no uniformity of standards.

so "The castle maxim, historically understood, never properly applied to the execution of criminal process, and the application of the rule of announcement was until very recently untested dicta." Blakely, supra, $n .2$ at 554.

n7 "[T]he general rule properly becomes not that announcement should be made but that entry should be peaceful. Forcible entry becomes than the exception. ..." Blakely, supra, n. 2 at 558.

vo Ho Quong et al. v. Cuddy (1914) 7 W.W.R. 797 (Alta. A.D.).

ny Eccles v. Bourque [1975] 2 S.C.R. 739.

su Comment, (1970) 80 Yale LJ. 139 at 142. And see Blakely, supra, n. 2 at 500 for a ureful treatment of the common law rules. 
was a prerequisite for justifiable forced entry. In all instances where Chief Justice Hale found forced entry authorized, he included a requirement of notice. ${ }^{91}$ Foster, in agreement, states the rule in broad terms:

[I]n every case where doors may be broken open in order to arrest, whether in cases of criminal or civil, there must be such notification, demand, and refusal, before the parties concerned proceed to that extremity. ${ }^{92}$

This is an absolute prohibition on unannounced entry; even hot pursuit will not serve to dispense with the requirement.93 Hawkins was equally clear that "no one can justify the breaking open another's doors to make an arrest, unless he first signify to those in the house the cause of his coming, and request them to give him admittance."94 Mr. Justice Chitty agreed that notice must precede entry. ${ }^{95}$

\section{A. Civil Process}

The source of the announcement rule is Semayne's Case. The fifth rule provides that in cases of civil process on third party premises after opening the doors, "the sheriff may break the house." 96 Although the third rule deals with criminal matters and is, strictly speaking, obiter, it has been widely followed in the cases of texts. It specifies before he, the sheriff, breaks it, "he ought . . to signify the cause of his coming, and make request to open the doors."97 An anonymous pamphlet published in 1659, on the excise and procedure of its enforcement-a form of general warrant which conferred apparently limitless powers of search-indicates that the one restriction on the search power was the requirement of announcement before entry. ${ }^{98}$ Moreover, an act of 1757 which provided for the issuance of warrants to search for pawned contraband specifically included a requirement of announcement, ${ }^{99}$ and a treatise writer's suggestion that no-knock powers for the police be legislated was treated as "a radical innovation."100 That the proposal was embodied in a general program for reform adds further evidence to the generality of the announcement requirement.101

The cases involving civil process have firmly entrenched the Semayne rule in the common law. In Waterhouse v. Saltmarsh, ${ }^{102}$ an inner door was broken after peaceful entry through an open outer door. Even though the sheriff had first knocked, he was held liable "for not signifying that he was the sheriff, that the door might have been opened without violence." 103 The exact same situation produced the same result

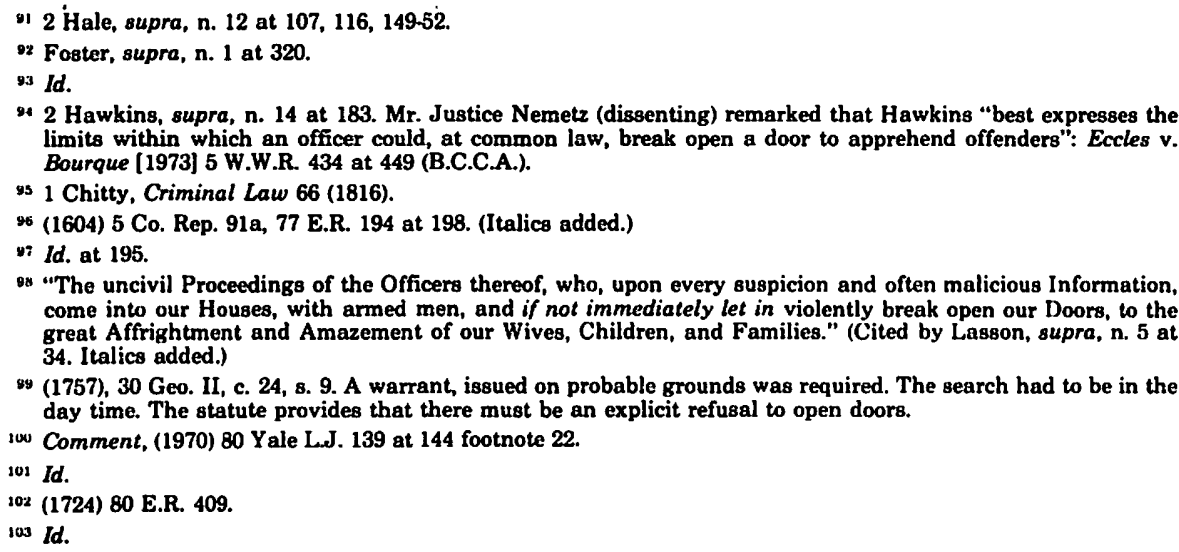
limits within which an officer could, at common law, break open a door to apprehend offenders": Eccles v. Bourque [1973] 5 W.W.R. 434 at 449 (B.C.C.A.).

951 Chitty, Criminal Law 66 (1816).

96 (1604) 5 Co. Rep. 91a, 77 E.R. 194 at 198. (Italics added.)

yi Id. at 195.

9s "The uncivil Proceedings of the Officers thereof, who, upon every suspicion and often malicious Information, come into our Houses, with armed men, and if not immediately let in violently break open our Doors, to the great Affrightment and Amazement of our Wives, Children, and Families." (Cited by Lasson, supra, $n$. 5 at 34. Italics added.)

w (1757), $30 \mathrm{Geo}$. II, c. 24, s. 9. A warrant, issued on probable grounds was required. The search had to be in the day time. The statute provides that there must be an explicit refusal to open doors.

100 Comment, (1970) 80 Yale L.J. 139 at 144 footnote 22.

101 Id.

102 (1724) 80 E.R. 409.

103 Id. 
in Ratcliffe v. Burton. ${ }^{104}$ In addition to the rule, the two cases are of more particular interest because the judges applied their minds to the reasons behind the rule and both concluded that it was an effective way to prevent violence. As Mr. Justice Heath observed, unannounced entry "must tend to create fear and dismay, and breaches of the peace by provoking resistance."105 This line of reasoning was developed further in Launock v. Brown:

If no previous demand is made, how is it possible for a party to know what the object of the person breaking open the door may be? He has a right to consider it as an aggression on his private property, which he will be justified in resisting to the utmost. ${ }^{106}$

A mere knock without identification is not sufficient, ${ }^{107}$ and there is dicta to the effect that in addition to identification, an explicit statement explaining the purposes of the officers is mandatory. ${ }^{108}$ The necessity for announcement before breaking inner doors was contradicted in two Common Pleas decisions, ${ }^{109}$ but the better opinion would appear to be that notification is necessary.100 Penton v. Brown is authority for the proposition that notice is not required before entry into a nondwelling, ${ }^{111}$ but the reason appears to be oriented to the law's view of the home as literally a castle-as protection from marauding violence outside. ${ }^{112}$ It is suggested that the better reasoning is that of the desirability of preventing violence developed in the later cases; thus this exception ought not to be followed. It has been held that entry without notice may be made for the purpose of rearrest after escape unless the notice "may be attended with some advantage, and may render the breaking open of the outer door unnecessary," 113 but the American cases dispute this in civil arrest. ${ }^{114}$ The qualification attached to the authority to dispense with notice fits so squarely into the rational framework of the old common law that it is difficult to believe any significant exception to the announcement requirement was intended. If it be treated as an expansion, the rule ought to be recognized as applying only in very rare situations and requiring a stringent test for justification. In the second entry situation, Canadian authority favors abrogation of the notice requirement for the officer "if the plaintiff was.. . apprised of his mission."115 The Restatement of the Law,

104 (1802) 3 Bos. \& Pul. 223, 127 E.R. 123. Rook J. concurred: "What a privilege will be allowed to sheriff s officers if they are permitted to effect their search by violence, without making that demand which possibly will be complied with, and consequently violence be rendered unnecessary." (Id. at 127.)

Lis: Id. at 126 .

100 (1819) 2 B. \& Ald. 592, 106 E.R. 482 at 483. The case involved a search warrant. A second line of reasoning is indicated in Semayne's Case-prevention of the destruction of property and the consequent sense of injustice and outrage this must produce. Protection of privacy has been suggested as a third rationale of the old common law. See Comment, (1970) 80 Yale L.J. 139 at 141 and footnotes therein cited.

10: Park v. Evans (1646), 80 E.R. 211. The point may be doubtful as the facts are extreme. The knock occasioned the plaintiff to open the door whereupon the defendants rushed in with drawn swords "and then used to the violence."

Iwm Per Bayley J. in Launock v. Brown (1819) 2 B. \& Ald. 529, 106 E.R. 482 at 483 (criminal process).

ter Hutchinson v. Birch (1812) 5 Taunt. 619, 128 E.R. 473; Lloyd v. Sandilands (1818) 8 Taunt. 250,129 E.R. 379.

11 Waterhouse v. Saltmarsh (1724) 80 E.R. 409; Ratcliffe v. Burton (1802) 3 Bos. \& Pul. 223, 127 E.R. 123. And see generally supra, n. 32

11 (1664) 1 Keeble 699, 83 E.R. 1193.

112 Semayne's Case (1604) 5 Co. Rep. 91a, 77 E.R. 194; Ryan v. Shilcock (1851) 7 Ex. 70, 155 E.R. 861 . However, Ho Quong et al. v. Cuddy (1914) 7 W.W.R. 797 (Alta. A.D.), criminal case authorizing entry without a warrant. maintained the distinction between dwelling house and other premises in holding notice was not required before entry into a non-dwelling house.

11.) See authorities cited supra, n. 38.

11. See authorities cited supra, n. 40.

11. Van Tassel v. Trask (1894) 27 N.S.R. 329. 
Second: Torts maintains the notice requirement in this situation "unless the actor reasonably believes such demand to be impractical or useless." 116 The Canadian position appears to be that the notice requirement is abrogated when notice is truly redundant, and it is to be preferred.

\section{B. Criminal Process}

The dictum that notice was a prerequisite for justifiable forced entry in criminal process appearing in the third rule of Semayne's Case was followed in $R$. v. Curtis. ${ }^{117}$ The eleven judges who heard the case were unanimous "that peace officers, having a legal warrant to arrest for a breach of the peace, may break open doors, after having demanded admittance and given due notice of their warrant."118 There is no authority found in the books to support a contrary rule for entry without warrant and such a proposition seems wrong on principle. The requirement of notice was upheld in one of the contempt cases. ${ }^{119}$ Chief Justice Abbott in Launock v. Brown ${ }^{120}$ held obiter that it was undecided "how far, in cases of persons charged with felony it be necessary to make a previous demand before breaking."121 But Bayley J. disagreed:

[E]ven in the execution of criminal process, you must demand admittance before you can justify breaking open the outer door. ${ }^{122}$

Hale and Foster ${ }^{123}$ specifically included a requirement of notice in the felony situation. A later dictum specified that the "Ceremony" of announcement need only "to be observed when it may possibly may be attended [sic] with some advantage, and may render the breaking open of the outer door unnecessary," 124 but as observed above this is best treated as an elaboration of the rational structure of the rule, rather than as a widening of police powers. Although there is American authority for the abrogation of the notice requirement in rearrest for felony, ${ }^{125}$ an American Surpeme Court judge in a relatively recent decision confessed that he could find no common law exception to the announcement rule. ${ }^{126}$ The older American cases preserved a notice of requirement for entry for felony. The exceptions to the rule are of recent origin. ${ }^{127}$

High Canadian authority has spoken to this question and a clear announcement requirement has thereby emerged. In Ho Quong et al. v. $C u d d y^{128}$ a search warrant issued to the Chief Constable by authority of section 641 of the Criminal Code provided for entry for purposes of arrest and gathering evidence "whether by breaking doors or otherwise."

\footnotetext{
116 Restatement of the Law, Second: Torts: No. 206(1).

11 (1756) Foster 135, 168 E.R. 67. The rule for the necessity of announcement in misdemeanours is so stated in an annotation at (1961) 76 A.L.R. (2d) 1432 at 1433. Only American authorities are cited.

"1s Id.

119 Burdett v. Abbot (1811) 14 East 1, 104 E.R. 501 (House of Commons warrant for contempt is assimilated to the criminal process). See also supra, n. 60.

120 (1819) 2 B. \& Ald. 529, 106 E.R. 482.

121 Id. at 483. Judgment was specifically reserved on the application of the requirement to criminal cases in Ratcliffe v. Burton (1802) 3 Bos. \& Pul. 223, 127 E.R. 123 at 217. (The latter case dealt with civil process.)

i.2 Id. at 483.

12: 2 Hale, supra, n. 12 at 107, 116, 149-152; and Foster, supra, n. 1 at 320.

124 Per Lord Campbell in Aga Kurboolie Mahomed v. The Queen (1843) 4 Moore 239, 13 E.R. 293 at 296.

${ }_{125}$ See Wilgus, supra, n. 20 at 804 and the footnotes therein cited.

126 Per Mr. Justice Brennan in Miller v. United States (1958) 357 U.S. 301 at 308.

${ }_{127}$ See e.g., Com. v. Reynolds (1876) 120 Mass. 190, 21 Am. Rep. 510; Com. v. Phelps (1911) 209 Mass. 396, 95 N.E. 868.

${ }^{12 N}$ (1914) 7 W.W.R. 797 (Alta. A.D.).
} 
Citing the rule in Launock v. Brown the court held the warrant there "unlawfully executed in as much as no demand of admittance had been made before breaking the outer door of . . . the plaintiff's house."128a The Penton v. Brown ${ }^{128 b}$ distinction between dwelling and non-dwelling premises was retained. Mr. Justice Beck held:

I think this rule is applicable to all search warrants or orders for search unless it is clear from the statute authorizing the search warrant that a demand to open is not necessary. The second preliminary to the execution of a search warrant is, generally speaking, when the place to be searched is a dwelling house, is a demand to open. ${ }^{29}$

Although the case has never been judicially cited, the British Columbia Court of Appeal ${ }^{130}$ and the Ontario Court of Appeal ${ }^{131}$ have laid down the identical rule although neither court considered the Penton v. Brown distinction. ${ }^{132}$

\section{Elements of Announcement}

The cases do not specify a distinction between the form of notice required in civil and criminal process and on principle such a distinction seems unfounded. A mere knock will not suffice. ${ }^{133}$ The minimum requirement on the books is a demand for admittance. ${ }^{134}$ Presumably the officer must wait a reasonable time for compliance before breaking doors-a time determined by the circumstances of the particular case. Demand and refusal satisfies the requirement. ${ }^{135}$ The requirement that the officer "signify the cause of his coming," in addition to a demand for admittance has been widely followed..$^{136}$ There appears to be no reason why the justification of entry by trick in civil process should not apply to the criminal process. ${ }^{137}$

\section{Exceptions to the Announcement Requirement}

At common law there are no exceptions to the announcement requirement. In all cases where a forcible entry is authorized notice must be given. In Canada, Ho Quong et al. v. Cuddy ${ }^{138}$ restricts the requirement to entry into a dwelling house, but it is suggested the literal application of such a rule is entirely too wide. Unannounced entry into a store or warehouse in the night-time, for example, is, if the premises be occupied, virtually certain to infringe the interests and values protected

121. Id. at 800 .

12ts (1664) 1 Keeble 699, 83 E.R. 1193.

129 Ho Quong et al. v. Cuddy (1914) 7 W.W.R. 797 (Alta. A.D.).

$130 R$. v. George (1935) 11 W.W.R. 145, 49 B.C.R. 345, 63 C.C.C. 225.

131 Restatement of the Law, Second: Tort: Nos. 204 and 206 adopts this position.

$132 R$. v. Beaudette (1957) 118 C.C.C. 295 . This case is not concerned with forcible entry. It deals with justified failure to notify an arrested person of the crime for which he is being arrested. The court was of the opinion that notification at the time of arrest may be dispensed with "where the reason for his arrest must have been perfectly obvious" to the accused (id. at 297). this reasoning, it is suggested, is not wothout interest to the forcible entry situation.

133 Park v. Euans (1646) 80 E.R. 211. But see the qualification supra, n. 107.

34 Per Bayley J. in Launcok v. Brown (1819) 2 B. \& Ald. 529, 106 E.R. 482 at 483; and per Rooke J. in Ratcliffe v. Burton (1802) 3 Bos. \& Pul. 223, 127 E.R. 123 at 127. And see Ho Quong et al. v. Cuddy (1914) 7 W.W.R. 797 (Alta. A.D.).

135 Burdett v. Abbott (1811) 14 East 1, 104 E.R. 501; and Foster, supra, n. 1 at 320.

136 Semayne's Case (1604) 5 Co. Rep. 91a, 77 E.R. 194; Ratcliffe v. Burton (1802) 3 Bos. \& Pul. 223, 127 E.R. 123; Van Trassel v. Trask (1894) 27 N.S.R. 329; and 2 Hawkins, supra, n. 14 at 136.

${ }_{137}$ The crucial point is that entry by trick does not infringe any of the values which the old common law judges protected by the announcement rule mitigation of violence, protection of property and privacy. But see Wong Sun v. United States (1936) 371 U.S. 471. The U.S. Supreme Court has held that proper announcement has three components: (a) announcement of presence (ringing bell or knocking), (b) identification as peace officers, and (c) explanation of lawful purpose. See Kerr v. United States (1963) 347 U.S. 23.

13s (1914) 7 W.W.R. 797 (Alta. A.D.). 
at common law. Van Tassel v. Trask ${ }^{139}$ may be viewed as dispensing with the requirement only in situations where it is redundant. ${ }^{140}$

The significant exceptions to the requirement thus, are entirely of American origin and it is the categories and language of the American decisions which are echoed by the Supreme Court of Canada in Eccles v. Bourque. ${ }^{141}$ The heterogeneous body of rules worked out in state decisions were organized around the constitutional axis of the Fourth Amendment in Mapp v. Ohio. ${ }^{142}$ The validity of the state exceptions came before the Supreme Court in Miller v. United States ${ }^{143}$ but the court found it unnecessary to decide "whether exigent circumstances justified dispensing with the rule requiring announcement." 144 Clark and Burton JJ. (dissenting) did note that the Court of Appeal had found "necessitous circumstances" which made "split second action necessary."145 In upholding the appellate decision on that ground, approval by dissent is given to the theory of abrogation of notice in exigent circumstances. Mr. Justice Clark returned to this question in Kerr v. California. ${ }^{146}$ Writing one of the majority judgments be held that mandatory notice would be abrogated in a situation where the fugitive had eluded the police immediately prior to arrest. ${ }^{147} \mathrm{As}$ has been noted: "This test would include, in theory, whole classes of crimes where the evidence to be seized was easily disposable."148 The judgment seems best interpreted as a return to a relatively unspecified concept of abrogation of the requirement by exigent circumstances first laid down in Miller v. United States. Brennan J. however, was exacting in specifying what constituted exigent circumstances which could serve as exceptions to the requirement of notice:

(1) where the persons within already know of the officer's authority and purpose, or (2) where the officers are justified in the belief that persons within are in imminent peril of bodily harm, or (3) where those within, made aware of the presence of someone outside (because, for example, there has been a knock at the door), are then engaged in activity which justified the officers in the belief that an escape or the destruction of evidence is being attempted. ${ }^{149}$

\section{NEW DIRECTIONS IN CANADIAN LAW: ECCLES $v$. BOURQUE}

The law of forcible entry was considered by the Supreme Court of Canada in its 1974 decision, Eccles v. Bourque. ${ }^{150}$ The facts of the case are not entirely clear. The defendants, three armed police officers in plain clothes, knocked on the plaintiff's door at about 4:00 p.m. on August 12, 1971. The door was opened slightly. One of the officers produced his

\footnotetext{
139 (1894) 27 N.S.R. 329.

140 . v. Beaudette (1957) 118 C.C.C. 295. And see supra, n. 131.

14 [1975] 2 S.C.R. 739.

162 (1961) 367 U.S. 643. And see infra Part IV, Section C.

${ }^{143}$ (1958) 357 U.S. 301

104 Id. at 309

145 Id.

146 (1963) 374 U.S. 23.

147 Id. at 40.

146 Comment, (1970) 80 Yale L.J. 139 at 148. Wigmore has considered the problem of destruction of evidence and concluded: "An officer's entry upon a party's premises or a seizure of a chattel for preservation as evidence, under a warrant, is a justifiable trespass." (See III Wigmore on Evidence 3029 at footnote 1 (1904).) Abrogation of notice, then, is a widening of the rule.

149 (1963) 374 U.S. 23 at 47. An excellent discussion of the values served by an absolute notice requirement, and a rule with exceptions is to be found in Comment, (1970) 80 Yale L.J. 139 at 150. An examination of the U.S. "no-knock" rule is available in Comment, (1971) $62 \mathrm{~J}$. Crim. L., Criminology \& Pol. Sci., 350; and Comment. (1970-71) Am. U.L. Rev. 467.

1so [1975]2 S.C.R. 739.
} 
badge and said, "Vancouver City Police." According to the plaintiff, while one of the officers stood at the door, the others pressed past the plaintiff and over his vociferous protests searched the suite without identifying themselves or their purpose. According to the defendants, the officers identified themselves and their purpose clearly before entering. ${ }^{151}$ The suite was entered and searched for the purpose of apprehending Edmund Cheese, a friend of the plaintiff known to frequent the plaintiff's apartment and for whom there were three outstanding Montreal warrants. Cheese was not found in the apartment. In an action for damages for trespass before Mr. Justice Wotton plaintiff recovered $\$ 300.00 .^{152}$ That decision was reversed by the British Columbia Court of Appeal ${ }^{153}$ and an appeal from that decision to the Supreme Court was dismissed.

\section{A. Forcible Entry Without a Warrant}

Counsel for the officers argued that if the officers were authorized by section 450(1)(a) of the Canadian Criminal Code to make an arrest, then by section 25 of the Code the authority extended to trespass for the purpose of making the arrest. Section $450(1)(a)$ is in effect a codification of the common law and provides as follows:

A peace officer may arrest without a warrant

(a) a person who has committed an indictable offence or who, on reasonable and probable grounds, he believes has committed or is about to commit an indictable offence.

The relevant portion of section $25(1)$ provides as follows:

Every one who is required or authorized by law to do anything in the administration or enforcement of the law

(b) as a peace officer or public officer

... is, if he acts on reasonable and probable grounds, justified in doing what he is required or authorized to do and in using as much force as is necessary for that purpose.

These are the only sections of the Canadian Criminal Code which are germane to the question. As such, the argument of counsel for the officers really comes to this: on these facts the right forcibly to enter follows the right to arrest. That argument called for a decision on two difficult points of law: (1) on reasonable suspicion that crime has been committed can an officer forcibly enter; and (2) on reasonable suspicion that the alleged criminal is on third party premises, can an officer forcibly enter? ${ }^{154}$ In rejecting the general proposition that the two sections of the Canadian Criminal Code provide that the right to enter follows the right to arrest, Dickson J., with whom three of the justices concurred, said:

I cannot agree with this submission. Section 25 does not have such amplitude. The section merely affords justification to a person for doing what he is required or authorized by law to do in the administration or enforcement of the law, if he acts on reasonable and probable grounds, and for using necessary force for that purpose. The question which must be answered in this case, then, is whether the respondents were

15) The facts are differently reported in the British Columbia Court of Appeal and the Supreme Court decisions. Robertson J.A., in the court of Appeal, writes that all three constables barged past the plaintiff (see [1973] 5 W.W.R. 434 at 435); while Dickson J., in the Supreme court, found that one constable remained at the door (see [1975] 2 S.C.R. 739 at 747).

152 Unreported.

15.) [1973] 5 W.W.R. 434 (B.C.C.A.).

ist For the position at common law, see supra Part II, section B. 
required or authorized by law to commit a trespass; and not, as their counsel contends, whether they were required or authorized to make an arrest. ${ }^{155}$

Martland J., with whom four of the justices concurred, wrote only a brief paragraph concurring with Dickson $J$. in the result but specifically reserving opinion on the reciprocal effects of sections 25 and 450 of the Canadian Criminal Code. ${ }^{155 a}$

If the court subsequently decides to accept the respondents' argument that section 25 in itself authorizes entry then the section will amount to a departure from common law which will vastly increase the occasion for forcible entry. Attention is drawn to the fact that section 25 would then provide authority for entry by a private person whereas at common law a private person could never enter on suspicion of felony. 156 Furthermore at common law, "[n]o crime was considered a felony, which did not occasion a total forfeiture of the offender's lands, or goods, or both."157 As Wilgus has noticed:

At common law an assault was a misdemeanour and it was still only such even if made with the intention to rob, murder, or rape. Affrays, abortion, barratry, bribing voters, challenging to fight, compounding felonies, cheating by false weights or measures, escaping from lawful arrest, eavesdropping, forgery, kidnapping, libel, mayhem, maliciously killing valuable animals, obstructing justice, public nuisance, perjury, riots and routs, etc., were misdemeanours. ${ }^{158}$

At common law, not only was forcible entry without warrant prohibited for these offences, but unless the offence were committed in the officers' presence, arrest without warrant was prohibited as well. The reclassification of these crimes makes mandatory either shifting the ground of the common law rule, or rethinking it. A vast expansion of the rule such as contemplated here totally upsets the logic of the law worked out over centuries. As indicated above, it is suggested that such an expansion would be most undesirable for the sound reasons given by the old common law judges. ${ }^{159}$ Any civilized legal system must not only profess high regard for the security of the individual, but guarantee that security in a fundamental way.

[I]t is the invasion of his indefeasible right of personal security, personal liberty and private property, where that right has never been forfeited by his conviction of some public offence-it is the invasion of this sacred right which underlies and constitutes the essence of Lord Camden's judgment [in Entick v. Carrington]. ${ }^{160}$

Dickson J., after finding that reasonable grounds existed to believe a criminal offence had been committed, held that the right to enter and search pursuant to the right to make an arrest without warrant under section 450 of the Canadian Criminal Code depended necessarily on the authorization to make a forcible entry at common law (section 25 of the Code did not grant such authority). Approaching the question in this way-if common law authorized forcible entry, section 450 authorizes forcible entry without warrant-Mr. Justice Dickson decided specifically: (1) on reasonable suspicion of a criminal offence forcible entry is

\footnotetext{
iss Eccles v. Bourque [1975] 2 S.C.R. 739 at 742.

1.. Id. at 748 .

15h See supra, Part II, section B.

1s: Kurtz v. Moffitt (1885) 115 U.S. 487 at 499.

1ss Wilgus, supra, n. 20 at 572-73.

159 See supra, n. 137.

isu Boyd v. U.S. (1886) 116 U.S. 661 at 630.
} 
justified, and (2) on reasonable suspicion that the alleged fugitive is on third party premises, forcible entry is justified.160a

It should be noted that this rule does not distinguish between those situations involving an indictable offence and those involving a summary offence. There is good reason in law and in policy for making such a distinction. Since the distinction between indictable and summary offences roughly parallels the old common law distinction between felonies and misdemeanours the restrictions on the right of forcible entry in the case of misdemeanours ought to be considered in relation to the right of forcible entry pursuant to a summary offence. Certainly forcible entry is an extraordinary procedure which ought to be enlarged only for the most compelling reasons. The old common law judges restricted recourse to this procedure where misdemeanours were involved and restricted it even more sharply if the misdemeanour did not amount to a breach of the peace.

It is submitted that the absence of this distinction in Eccles $v$. Bourque ought not to be interpreted as widening the rule.

Although the language of the judgment-"criminal offence,"161 "criminal fugitive,"162 "criminal process,"163-contains implications that forcible entry may be made for any criminal offence, strictly speaking on the facts of the case it could only be used as obiter for this proposition. If a subsequent court should accept the wider rule involving all criminal offences, it would be a significant and undesirable expansion of police powers. At common law the police had no such general authority forcibly to enter without a warrant for misdemeanour. ${ }^{164}$

More importantly, at common law, the only authority which exists in cases for the proposition one may enter without a warrant to search for a criminal fugitive whom one suspects to be on the premises is contempt cases. That alone offers an important ground of distinction, the more so on the facts as contempt is not a felony. ${ }^{165}$ Moreover, in all three cases the premises involved were occupied by the fugitive; they were not third party premises. Davis v. Russell, , $^{166}$ the only other case possibly relevant, also did not involve third party premises. As noted above, the text writers disagree on this subject. Therefore, the Supreme Court has laid down the two new rules. These rules legitimize wide powers for the police which have been bitterly disputed by the text writers, at times on constitutional grounds. It would have been helpful to have the Court's thinking on the reasons behind these rules-at least that would have provided guidance in the determination of reasonable and probable grounds. As already stated, the only consistent ground for rationalizing the authorities is to treat such an entry as a highly extraordinary act. Certainly this was the tenor of Nemetz J.A.'s dissent in Eccles v. Bourque in the Court of Appeal. His thinking would appear to have been influenced by Hawkins' dictum that only in "cases of necessity" does the law allow this procedure. ${ }^{167}$ This thinking is energized by a healthy

\footnotetext{
1000 Eccles v. Bourque [1975] 2 S.C.R. 739 at 742.

161 Id. at 741 .

162 Id. at 744.

163 Id. at 745.

164 See supra, Part II, section B.

165 See supra, nn. $60 \& 61$

166 (1820) 5 Bing. 354, 130 E.R. 1098.

${ }^{67}$ Eccles v. Bourque [1973] 5 W.W.R. 434 at 450-51 (B.C.C.A.).
} 
apprehension of significantly expanding police powers of forcible entry.

Clearly probable cause determination will have to occupy the mind of the Court in subsequent cases. Hopefully, forcible entry without warrant by the police will not be treated as an ordinary procedure. On these facts, for the reasons given by Nemetz J.A., ${ }^{168}$ it is not at all clear that "reasonable and probable grounds" has been imbued with the stringent judicial control which such facts require. It is suggested that reasonable and probable grounds ought to imply two things: (1) objective reasons determined by the Court for believing (a) that an indictable offence has been committed and (b) that the supposed criminal is on the premises; and (2) necessitous circumstances requiring the extraordinary procedure of forced entry without a warrant to be employed. Furthermore, it is suggested that the constitutional dimensions of protection from arbitrary police entry deserve attention.

\section{B. Announcement}

There can be little doubt that in Eccles v. Bourque the Supreme Court made serious inroads into the common law requirement of notice before forcible entry. At common law there are no exceptions to the announcement requirement. Ho Quong et al. v. Cuddy' 169 introduced the Penton v. Brown ${ }^{170}$ distinction between dwelling and non-dwelling premises based apparently on the court's desire for consistency in legal classification rather than on sound policy. This infringement of the notice requirement might have been, but was not, reviewed by the Court. What the court did do was to adopt the American exceptions, thus seriously diminishing the protection of the rule. "Except in exigent circumstances, the police officers must make an announcement prior to entry."171 Those two words-"exigent circumstances"-provide a bridge to the entire body of American jurisprudence. The approach favoured by the Court appears to be that of Mr. Justice Brennan in Kerr v. California, ${ }^{172}$ an enumeration of the exigent circumstances constituting exceptions to the notice requirement-although in the Eccles decision the words "exigent circumstances" appear unattached to any enumeration, ${ }^{173}$ suggesting, in line with Mr. Justice Clark in Miller v. United States, ${ }^{174}$ the categories of exceptions are not closed. The Supreme Court in the Eccles case provides an enumeration of situations that may abrogate mandatory notice:

[I]t is recognized there will be occasions on which, for example, to save someone within the premises from death or injury or to prevent destruction of evidence or if in hot pursuit notice may not be required. ${ }^{175}$

The judgment, then, is a significant expansion of the common law police powers of forcible entry. It effectively introduces a no-knock provision into Canadian law in the three situations enumerated by the Court, and there is every reason to believe that these situations are not exhaustive.

The destruction of evidence situation is the most alarming exception

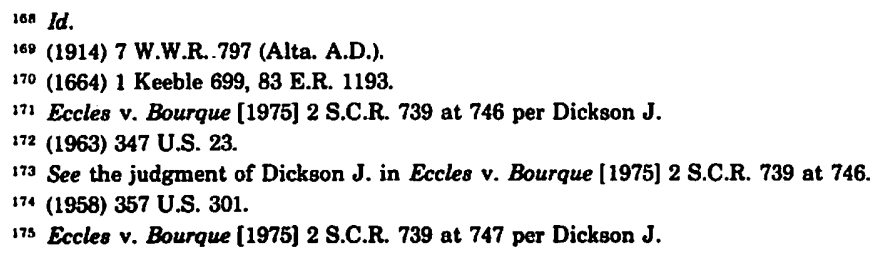


to the announcement rule. It seems to be directed at the problems faced in the legal control of narcotics and gambling. These activities, apart from those undertaken by organized and professional criminals, are hotly contested contemporary issues and certainly involve a significant, indeed, according to the Royal Commission on the Non-Medical Use of Drugs, a huge portion of our population. It is suggested that giving the police a pass key to Canadian homes will do little to aid the goals professed by supporters of the exceptions-effective law enforcementand, by containing the possibility of exacerbating police-community relations, may seriously undermine that goal.

It is perhaps worth noting that the development of American law around the exigent circumstances theory has not demonstrably stemmed the rising tide of American crime, although it is admitted that this observation has at best negative value. Certainly one suspects it has done nothing to improve police-community relations.

Nevertheless, the supporters of a no-knock provision have made a case during the Senate and House debates on the United States legislation. In view of the Eccles v. Bourque decision it is of importance that Canadian debate take account of it. A "destruction of evidence exception," it is said, adds to the speed and surprise of the police. The approximately thirty seconds saved by dispensing with the requirement is necessary to deal with the sophisticated methods of organized crime. The U.S. House of Representatives was impressed, in this regard, with the committee report on H.R. 16196, 1970:

In $1962 \ldots$ it was reported that less than 30 seconds were necessary to destroy all the evidence of a wire service headquarters. . . Experience has shown that numbers bets are recorded either on flash paper which ignites on contact with fire or 'water soluble' paper which dissolves on contact with water, and that the time spent by the executing officer in giving notice and waiting to be refused admittance is used by the drug trafficker in disposing of his narcotics down the toilet. ${ }^{176}$

This, undoubtedly, is a weighty argument and one which deserves consideration in the light of Canadian experience. It should also be noted that the threat of police harassment-perceived as well as real-is lessened by the requirement for a warrant to enter and search a dwelling house for suspicion of narcotics. ${ }^{177}$ Against these considerations must be weighed the infringement of what are fundamental values of our democracy - the sanctity of the home, the protection of property, privacy and its corollaries of freedom from interference and from the fear of interference in legitimate activity, and reduction of the opportunities for violence. ${ }^{178}$ In stating this, nothing new is being said for these were the values which the old common law judges sought to protect by the creation and maintenance of the announcement requirement. Furthermore, it is by no means clear, it is submitted, that infringing these values aids effective law enforcement. As has already been noted, exacerbation of police-community relations by flouting the basis of

${ }^{176}$ House Comm. on the District of Columbia, Report on H.R.16196, District of Columbia Court Reform and Criminal Procedure Act of 1970, H.R. Report No. 907, 91 st Cong., 2nd Sess. 108.109 (1970), cited in Comment. (1970) 80 Yale L.J. 139 at 150 footnote 52 (and see the commentators' thoughtful remarks at 150-55).

177 Narcotic Control Act, R.S.C. 1970, C.N.-1, as amended by S.C. 1972, c. 17, 8s. 2(1) \& 10(1).

174 This last assumes an especial significance in face of the incresing arming of the population in expectation of violent criminal entries. Although Canadian statistics are not available, it is helpful to consult U.S. National Commission on Causes and Prevention of Violence, Report (1969). It has also been suggested that the police have used unannounced entry to draw fire, thus justifying a large scale prepared counter.attack. It was suggested in the New York Times, May 16, 1970 at 1 , col. 1, that this may have been the case in the raid on the headquarters of the Chicago Black Panther Party which resulted in the deaths of Mark Clark and Fred Hampton. See Comment, (1970) 80 Yale L.J. 139 at 153 and the footnotes therein cited. 
constitutional democracy is sure to undermine it. A possible misuse of no-knock powers must, therefore, be an anxious cause for concern.

\section{Elements of Announcement}

In Eccles v. Bourque the court favoured a strict approach to the required elements of notice.

In the ordinary case police officers, before forcing entry, should give (i) notice of presence by knocking or ringing the doorbell, (ii) notice of authority, by identifying themselves as law enforcement officers and (iii) notice of purpose, by stating a lawful reason for entry. ${ }^{179}$

This is in line with the authority flowing form the dictum in Semayne's Case $^{179 a}$ and developed by Heath J. in Ratcliffe v. Burton. ${ }^{180}$ Apparently in exceptional circumstances, an explicit statement explaining the purpose and lawful reason for entry may be dispensed with. "Minimally they [the officers] should request admission and have admission denied."181 Presumably this minimal requirement is not sufficient "in the ordinary case."182 This appears a sensible qualification to the announcement of purpose rule, which requires notice of purpose and lawful authority.

Mr. Justice Dickson's judgment is helpful in recalling those "compelling considerations" which occupied the minds of the old common law judges. As he writes:

An unexpected intrusion of a man's property can give rise to violent incidents. It is in the interests of the personal safety of the householder and the police as well as respect for the privacy of the individual, that the law requires, prior to entrance for search and arrest, that a police officer identify himself and request admittance. ${ }^{183}$

These considerations have touched the minds of judges in every legal system since Hammurabi's Code. The announcement rule, first laid down in English law by Lord Coke, was enshrined in British constitutional practice by the eighteenth century English judiciary. Lord Camden's judgment in Entick v. Carrington 184 exudes confidence that a balance can be struck between requisite police powers for effective law enforcement and constitutional protection from arbitrary interference in order that both serve the common end of public welfare. If flash paper and water-soluble paper are indeed capable of upsetting that balance, it may become necessary to rethink Lord Camden's optimism.

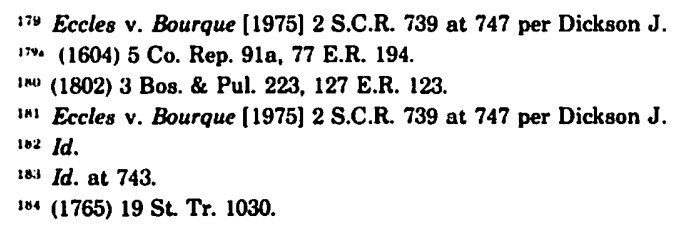

